\title{
Mechanical evaluation of bone gap filled with rigid formulations castor oil polyurethane and chitosan in horses
}

\author{
Avaliação mecânica do preenchimento de falhas ósseas de equinos com \\ formulações sólidas de poliuretana de mamona e quitosana \\ Rodrigo Crispim Moreira ${ }^{I^{*}}$ Guilherme Maia Mulder Van De Graaf ${ }^{1}$ \\ César Augusto Pereira" André Luis do Valle De Zoppa ${ }^{\text {III }}$
}

\section{ABSTRACT}

Often fractures of long bones in horses are comminuted and form bone gaps, which represent a major challenge for the fixation of these fractures by loss of contact between the fragments. Bone grafts help in treating this kind of fracture and synthetic materials have been gaining ground because of the limitations of autologous and heterologous grafts. In this study were performed compressive non destructive test in 10 bones with complete crossbone gap in mid-diaphyseal of the third metacarpal bone of horses. Using a mechanism of "crossing" the 10 bones were used in the three groups (control, castor oil poliuretane and chitosan) according to the filling material. After the test with maximum load of $1000 \mathrm{~N}$ bone had a gap filled by another material and the test was repeated. Deformations caused on the whole bone, plate and bone tissue near and distant of gap were evaluated, using strain gauges adhered to the surface at these locations. There was a reduction in bone deformation from $14 \%$ (control) to $3,5 \%$ and $4,8 \%$ by filling the gap with Chitosan and castor oil respectively and a reduction of strain on the plate of $96 \%$ and $85 \%$ by filling gap with chitosan and castor respectively. An increase in intensity and direction of deformations occurred in bone near to gap after its filling; however, there was no difference in bone deformations occurring far the gap.

Key words: equine, fracture, biomaterial, strenght, biomechanical test.

\section{RESUMO}

Frequentemente, as fraturas de ossos longos nos equinos são cominutivas, formando falhas ósseas, que representam um grande desafio no momento de sua fixação, devido à perda de contato entre os fragmentos. Os substitutos ósseos sintéticos auxiliam no tratamento desse tipo de fratura. Neste estudo, foram realizados ensaios compressivos não destrutivos em 10 ossos com falha óssea transversal completa em diáfise do terceiro metacarpiano de equinos. Utilizando um mecanismo de "crossing", os 10 ossos foram utilizados nos três grupos (controle, mamona e quitosana) de acordo com o material de preenchimento da falha. Para cada peça, realizaramse ensaios referentes aos três grupos, com carga máxima de $1000 N$, por não se tratarem de ensaios destrutivos. Foram avaliadas as deformações causadas no osso, na placa e no tecido ósseo próximo e distante da falha, por meio de extensômetros. Observou-se que houve redução da deformação do osso de $14 \%$ (controle) para 3,5\% e 4,8\%, com o preenchimento da falha com quitosana e mamona, respectivamente. Houve redução da deformação na placa de $96 \%$ e $85 \%$ com o preenchimento da falha com quitosana e mamona, respectivamente. Houve aumento em intensidade e direção das deformações ocorridas no osso próximas à falha após seu preenchimento, contudo não se observaram diferenças nas deformações ocorridas no osso distantes a falha. Dessa forma, conclui-se que o preenchimento das falhas com quitosana e poliuretana de mamona trouxe beneficios quanto à redução das deformações no foco da fratura, alivio das cargas na placa, contudo elevou as cargas no tecido ósseo próximo à falha.

Palavras-chave: equino, fratura, biomaterial, resistência, teste biomecânico.

\section{INTRODUCTION}

Long bone fractures in adult horses are often comminuted. Resulting bone gaps interfere with

\footnotetext{
IPrograma de Pós-graduação em Veterinária e Cirurgia (VCI), Faculdade de Veterinária e Zootecnia (FMVZ), Universidade de São Paulo (USP), 15053-794, São José do Rio Preto, SP, Brasil. E-mail:crispimr@hotmail.com. Corresponding author.

IInstituto de Ortopedia (IOT), Faculdade de Medicina e Zootecnia (FMVZ), Universidade de São Paulo (USP), São Paulo, SP, Brasil.

IIIDepartamento de Cirurgia, Faculdade de Medicina Veterinária e Zootecnia (FMVZ), Universidade de São Paulo (USP), São Paulo, SP, Brasil. 
force transmission through the fracture site, leading to orthopedic implant overload (NIXON, 1996).

Bone grafts are required to eliminate large bone gaps. Autografts are more commonly employed, but availability is limited and harvest morbidity must be considered, while allografts carry the risk of disease transmission and immune reactions (CALORI et al., 2011). Such concerns have fostered the search for synthetic, mechanically resistant bone substitutes for improved fracture stabilization in horses.

Over the last few years, the natural polymer chitosan has received increasing attention as a potential tissue gap filling alternative. Chitosan-based polymers have been successfully employed in treatment of periodontal bone lesions and bone defects and have been shown to stimulate new bone formation, as demonstrated in histological sections and in a wide variety of clinical tests (SPIN-NETO et al., 2008).

LISTONI (2013) evaluated bone marrowderived stem cell growth and osteogenic/chondrogenic differentiation following culture in chitosan/hyaluronic acid hybrid films and concluded that these membranes are able to support bone tissue repair.

Chitosan may also be added to inorganic biomaterials such as hydroxyapatite and betatricalcium phosphate; mechanical characteristics are enhanced and biocompatibility is maintained (GINALSKA \& PRZEKORA, 2014).

A polymer containing beta-tricalcium phosphate, chitosan and platelet rich plasma (PRP) has been developed for bone bioengineering application; PRP did not interfere with biomechanical properties and the polymer was shown to induce stem cell proliferation and differentiation into in vitro osteoblasts (BI et al., 2010).

Hydroxyapatite, beta-tricalcium phosphate and chitosan have also been employed to develop a hybrid material with similar biocompatibility to chitosan and capable of withstanding load; the polymer was shown to act as a scaffold for bone cell culture and sufficiently high modulus of elasticity and load resistance have been demonstrated (ZHANG \& ZHANG, 2002).

Castor oil polyurethane is a natural product derived from two basic castor oil components: polyol and pre-polymer. Castor oil polyurethane was shown to have similar characteristics to human bone permitting osteogenesis between fractured fragments, with no foreign body reaction (BOLSON et al., 2005).

Progressive connective and ostechondroid tissue formation at the bone/polyurethane interface has been described upon histological evaluation within $15,30,45$ and 60 days of castor oil polyurethane implantation in murine femur, again with no foreign body reactions (MARTINELI JÚNIOR, 2011).

Modulus of elasticity values of 328.265MPa and 1354.284MPa have been described following axial compression of both, porous and compact castor oil based polyurethane (with and without bubbles respectively). These values are lower than average values reported for the equine cortical bone, but similar to those documented in the trabecular bone of the equine third metacarpus (6093Mpa and 1174Mpa respectively) (VAN DE GRAAF, 2012).

A polyurethane/calcium mixture, alone or combined with bone marrow, has been tested in bone gap repair in rabbits; calcium has been shown to increase polyurethane porosity, with penetration of new bone tissue through the more superficial pores in the biomaterial (DEL CARLO et al., 2003).

Clinical and radiographic assessment of experimental bone gaps filled with castor oil polyurethane in horses revealed increased local inflammatory reaction and slower bone healing (DORNBUSCH et al., 2010).

\section{MATERIALS AND METHODS}

Five equine third metacarpal bone pairs were used in this study. Bone specimens were harvested from cadaver limbs and stored in a horizontal freezer until use. Specimens were thawed and the second, third and fourth metacarpal bones separated for locking compression plate (LCP) application. An 11-hole LCP was implanted at the dorsal aspect of the third metacarpal bone and a $1 \mathrm{~cm}$ bone gap created in the mid diaphysis; proximal and distal bone ends were sawed off to produce flat, parallel articular surfaces amenable to attachment to a biomechanical testing machine.

Biomechanical testings were performed using a universal testing machine $\left(\mathrm{KRATOS}^{\circledR}\right.$, $\mathrm{K} 5002$ ) and a special device was designed to hold the distal and proximal bone epiphyses in place during biomechanical trials.

Castor oil polyurethane was prepared using an analytical. Following addition of $0.65 \mathrm{~g}$ of polyol and 0.82 grams of calcium carbonate per gram of pre-polymer, components were mixed for approximately 6 minutes to obtain a firm solution. Resulting polyurethane was then placed in $6 \mathrm{~cm}$ cylindrical Teflon molds of variable height. In order to prevent bubble formation during the polymerization process, expansion was controlled via a 590 gram pushing tube connected to a $5 \mathrm{~kg}$ weight. 
High component concentration in the formula (chitosan powder, distilled water, citric acid, dextrose and beta-calcium triphosphate; 1.36 , $63.65,60.08$ and 104.78 grams respectively) required gradual addition of the different components to facilitate homogenization. Hence, the procedure involved four consecutive steps (VAN DE GRAAF, 2012), as follows:

First, a 2\% chitosan hydrogel was prepared using chitosan, water and citric acid (1, 36.5 and 12.5 grams respectively). Then, chitosan, citric acid and dextrose $(0.125,1.023$ and 1.2016 grams per gram of hydrogel respectively) were added to the mixture to form a paste-like substance within approximately 5 minutes. Calcium triphosphate was then added $(0.65$ grams per gram of paste) to yield a firm substance. Finally, the final substance was transferred to Petri dishes $(16 \mathrm{~mm}$ height $\mathrm{x} 60 \mathrm{~mm}$ width) and incubated at $38^{\circ} \mathrm{C}$ for 24 hours.

This study involved compressive, nondestructive biomechanical testings. Two specimens were used for determination of the load to be employed; the first was submitted to destructive testing for elastic limit determination while the second was submitted to repeated non-destructive compression to evaluate potential changes between two consecutive testings. Changes were not observed; therefore, the maximum load was set at 1000 newtons $(\mathrm{N})$ and applied to the central bone axis at a speed of $5 \mathrm{~mm} / \mathrm{min}$.

This study involved three groups: Control (ND-C); castor oil polyurethane (ND-M) and chitosan (ND-Q). Using the crossing design described by ULIAN et al. (2008), all ten specimens were used in all three groups. Following mechanical testings in one group, the same specimens were used in the other group in a different order.

Strain gauges can be attached to the surface of target materials to provide site-specific strain readings. Strain gauges were used in this study to determine deformations at specific sites on the plate and bone. One uniaxial strain gauge was attached to the midpoint of the dorsal aspect of the plate and triaxial strain gauges were placed on the bone as follows: one medial and one lateral, $1 \mathrm{~cm}$ distal to the gap; one on the palmar aspect, between the $3^{\text {rd }}$ and $4^{\text {th }}$ screws, approximately $5.5 \mathrm{~cm}$ from the gap (Figures $1 \mathrm{~A}$ and $4 \mathrm{~B}$ ). Uniaxial gauges were intended for assessment of the load transmitted by the plate and triaxial gauges to assess strains close to and away from the bone gap. In this manner, strains in the whole construct (i.e., on the plate, close to and away from to the bone gap) could be sampled during biomechanical testings.

\section{RESULTS AND DISCUSSION}

Time and procedural differences were noted in the preparation process of castor oil polyurethane and chitosan. Ease and speed of castor oil polyurethane preparation permits intraoperatively applicability, with proper fitting into gaps of different shapes (JACQUES, 2004); in contrast, chitosan required previous preparation in pre-defined shapes, translating into more difficult fitting.

This study involved non-destructive testings with loads up to $1000 \mathrm{~N}$, which are lower than the actual loads experienced by the limb of an adult horse at walk (7500N at the mid third metacarpal diaphysis; LES et al. 1998). However, such loads are believed to be close to those applied to the limb by smaller animals, or in the presence of a painful fracture.

Bearing these load magnitudes in mind, destructive testings, along with application of values corresponding to in vivo loads experienced by foals and adult horses during anesthetic recovery from long lasting procedures (e.g., orthopedic surgeries) would be required to determine maximal loads tolerated by bone gap filling materials such as those in this study.

Construct (bone/ plate/ gap with or without filling) deformation was observed in all groups in this study, with different intensities (Dunnett's test; $\mathrm{P}<0.05$ ), with decreased construct length due to plate bending. Greatest and smallest deformations were documented in the control and chitosan group respectively (Figure 2). Lower levels of deformation following chitosan application possibly reflect the greater rigidity of this biomaterial (VAN DE GRAAF, 2012).

Mobility at the fracture site has a negative impact on fracture healing (HAK et al., 2010). In this study, reduction of $14 \%$ and $3 \%$ in deformation under loads up to $1000 \mathrm{~N}$ following application of synthetic implants (castor oil polyurethane and chitosan respectively) was observed. Therefore, bone gap filling with these biomaterials was thought to be beneficial.

Biomaterial porosity enhances nutrient penetration and biomaterial incorporation at the expense of mechanical resistance (VAN DE GRAAF, 2012). Horses are heavy, irrational animals; hence biomaterial mechanical resistance should be prioritized over biological behavior in this species.

Loads applied to fractured bone epiphyses are transmitted through apposed fracture fragments and/or implants employed for fracture fixation. Therefore, the greater the load transmitted through the implant, the greater the deformation on the implant surface. 

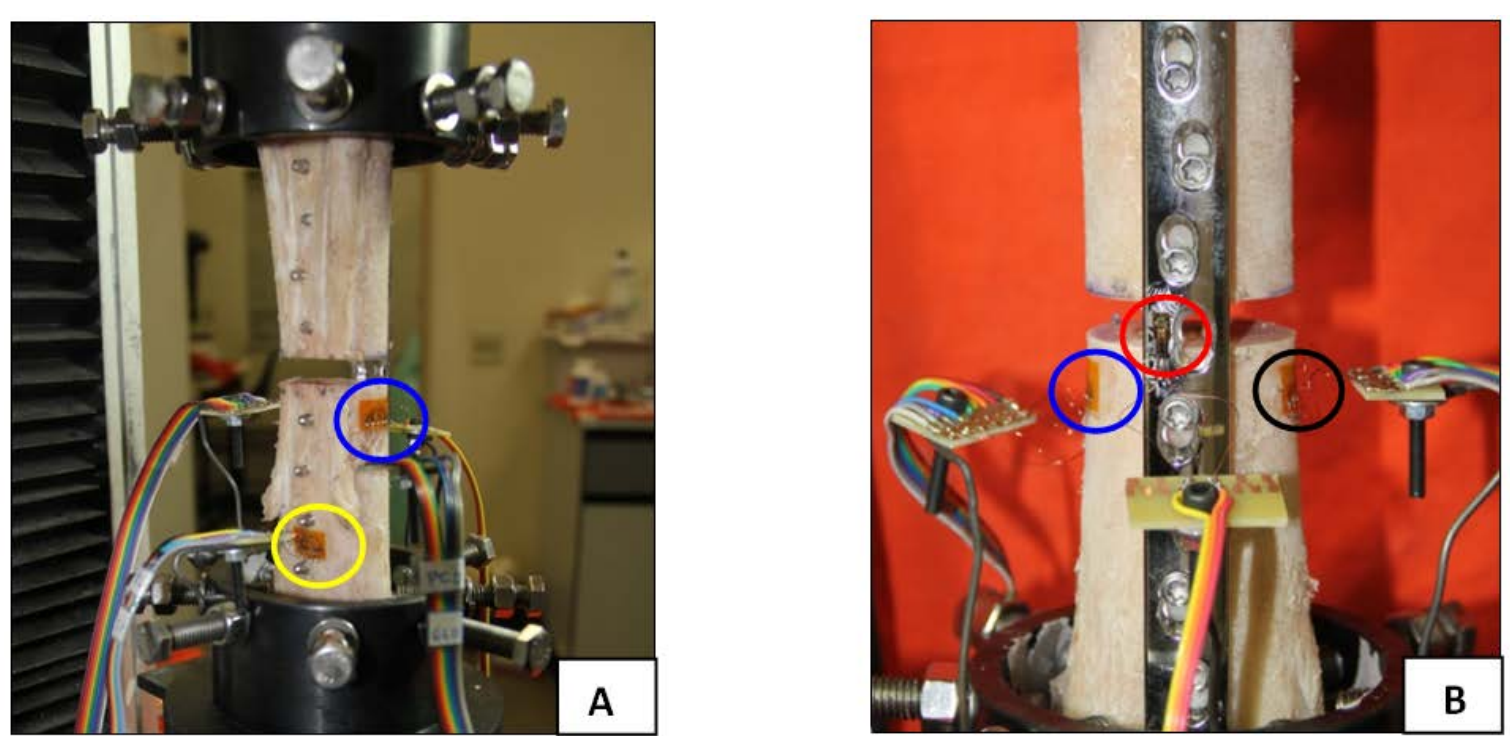

Figure 1 - Construct with strain gauges attached to the biomechanical testing machine.

Right third metacarpal bone and strain gauges attached to the biomechanical testing machine. A: Palmarolateral view showing lateral (blue circle) and palmar (yellow circle) strain gauges. B: cranial view showing plate (red circle), lateral (blue circle) and medial (black circle) strain gauges. Source: (MOREIRA, R. C., 2014).

Deformations documented on the plate surface differed significantly between tested groups and between tested and control groups in this study (Dunnett's test; $\mathrm{P}<0.05$ ), with $85 \%$ and $96 \%$ reduction in plate deformation under loads up to $1000 \mathrm{~N}$ following application of castor oil polyurethane and chitosan implants respectively (Figure 3). Implant overload is one of the major problems in fracture treatment

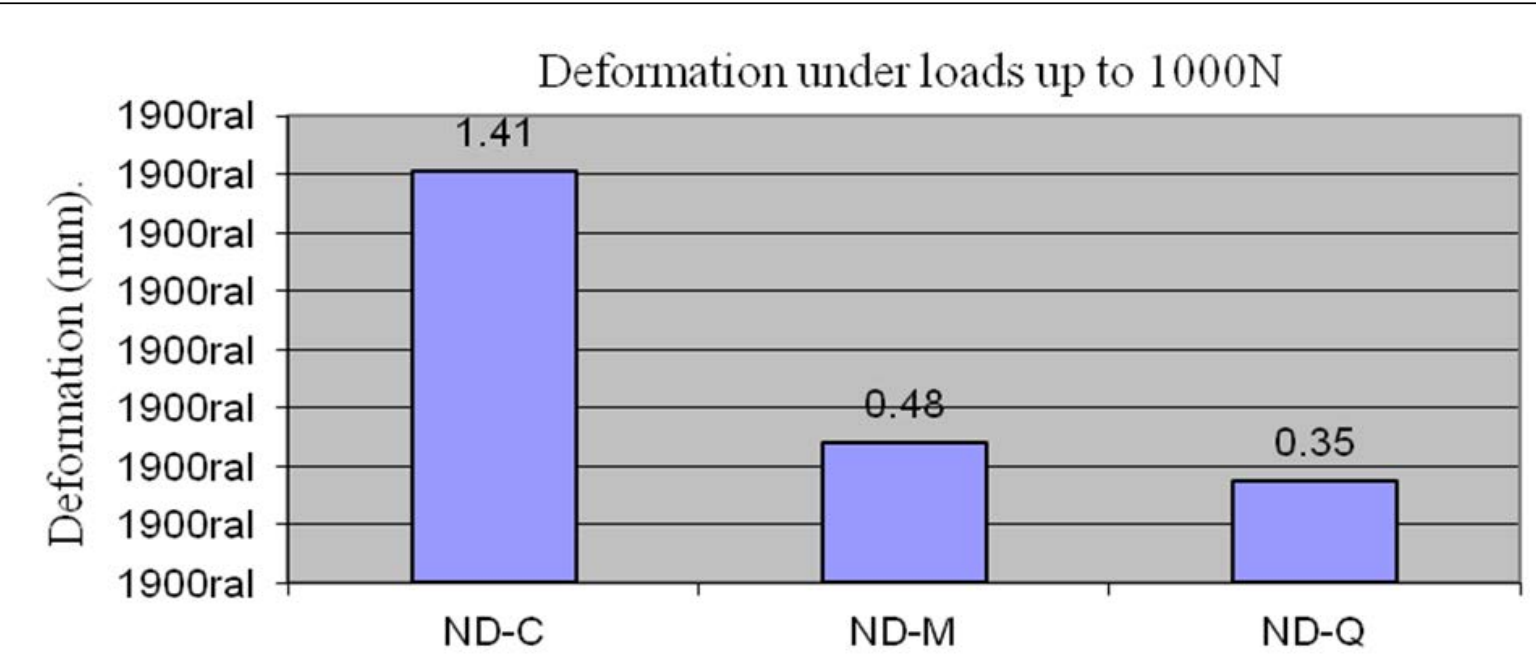

Figure 2 - Graphic representation of construct deformations sampled by the mechanical testing machine.

Bar chart showing mean deformation values sampled by the mechanical testing machine in the control (ND-C), castor oil polyurethane (ND-M) and chitosan (ND-Q) groups. Source: (MOREIRA, R. C., 2014).

Ciência Rural, v.46, n.12, dez, 2016. 


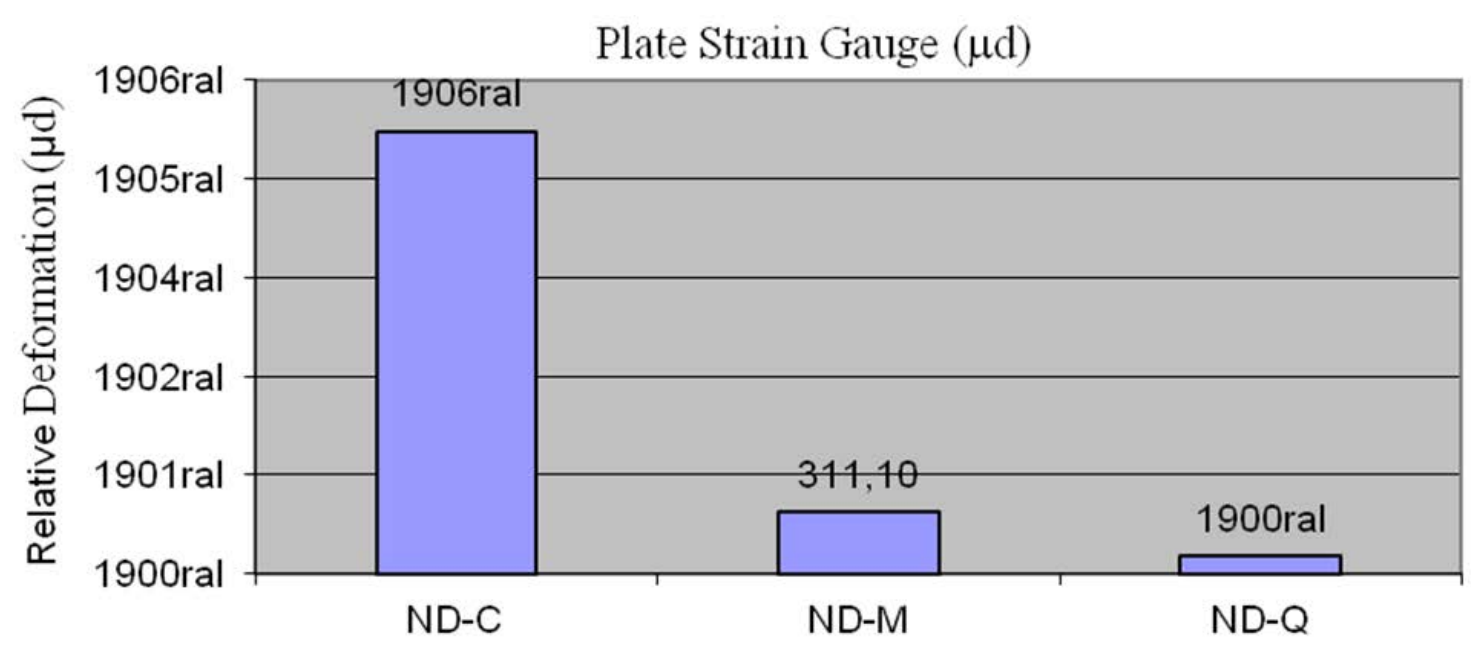

Figure 3 - Deformation readings given by uniaxial strain gauges attached to the plate mid-point, in each group.

Bar chart showing mean plate deformation values sampled via a uniaxial strain gauge (mm), in the control (ND-C), castor oil polyurethane (ND-M) and chitosan (ND-Q) groups. Note positive values (i.e., tension on the plate surface). Source: (MOREIRA, R. C., 2014).

in horses (NIXON, 1996), and can be mitigated by load reduction via inclusion of biomaterial implants in osteosynthesis procedures. That doesn't mean that implants alone have the ability to prevent implant failure. Most implants used in horses are originally designed for humans; therefore, plaster casts and anesthetic recovery support are paramount for load reduction at the fracture site.

When loads are transmitted through apposed fracture fragments or biomaterial implants, contact surfaces will be loaded; the greater the force transmission through the fracture, the greater the deformation in bone tissues, which must be able to withstand such loads.

Strain gauges in gap vicinity revealed intergroup differences not only regarding deformation intensity, but also deformation direction (Figure 4). In contrast, readings sampled via palmar strain gauges placed $5.5 \mathrm{~cm}$ away from the gap did not differ between groups (Figure 5). Therefore, increased loads resulting from filling of bone gaps with rigid biomaterials were limited to gap vicinity. Load distribution through the bone and plate screws likely prevented loads transmitted through the biomaterials to act at more distant sites.

Load transmission through biomaterials implants decreased total bone and plate deformation in this study, with increased loads on bone surfaces restricted to bone gap vicinity. Results presented suggested that bone gap filling with the biomaterials studied may bring biomechanical advantages to ostheosynthesis procedures.

The fact that it was used only mechanical testing suggests that the present study presented limitations for the immediate use of the evaluated materials, as clinical use are needed for other evaluations, such as behavior of these materials in biological systems. In this respect, the castor oil polyurethane presented in a more advanced stage, is already available for use in human orthopedics. However, chitosan formulation investigated differs from other formulations already employed and thus needs further evaluation for in vivo use.

These laboratory tested to assess the mechanical behavior ofimplants used in orthopedics and, in this study, the bone defect filling with biomaterials used brought Biomechanical osteosynthesis benefits to increase the strength and rigidity of the orthopedic implant / biomaterial / bone, to reduce the loads in which the implant was subjected due to the transmission of loads by biomaterial, which led to an increase in load on the bone surface next to the defect. Considering the mechanical behavior and the mechanical demands of osteosynthesis, it is possible to suggest that chitosan presents possibility of bringing greater benefit in filling bone of horse failures. 


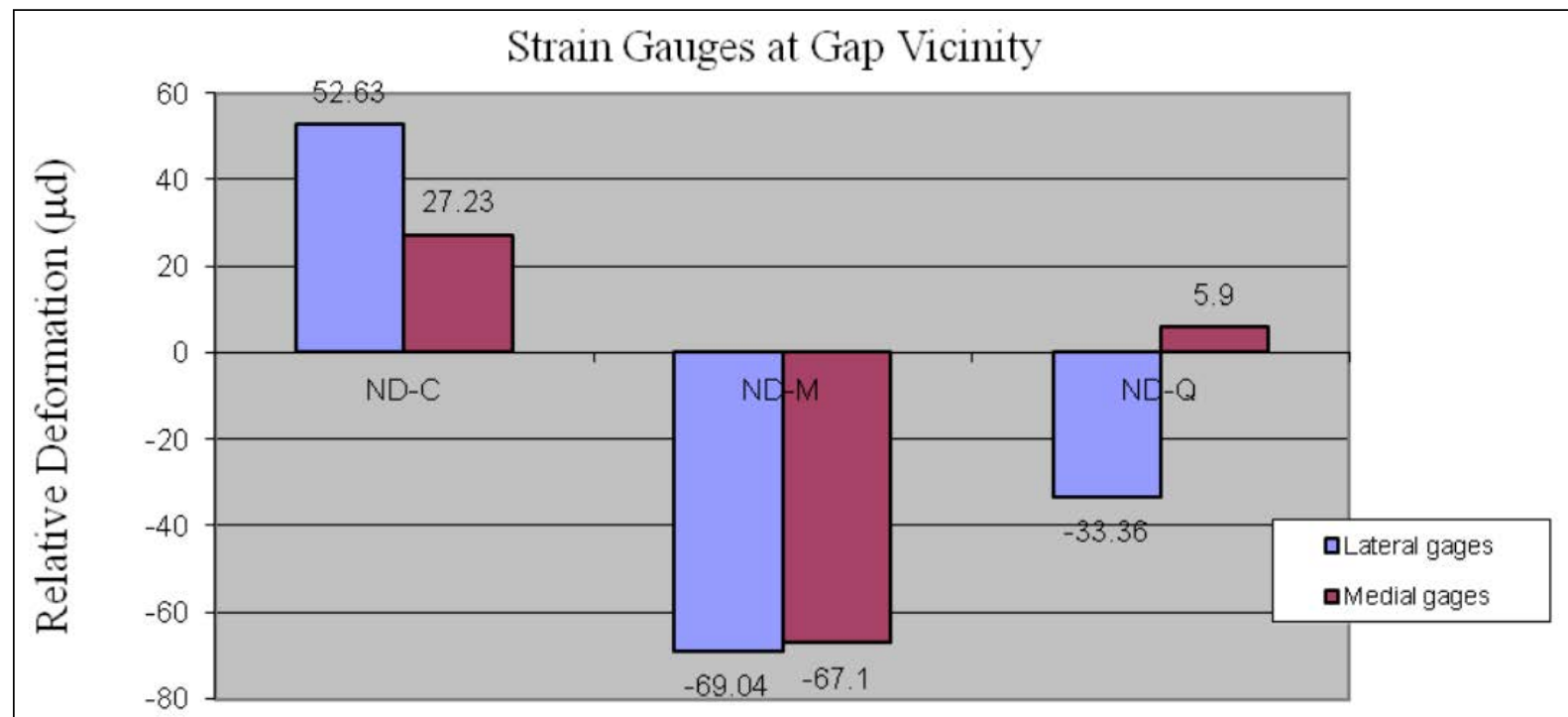

Figure 4 - Deformation readings given by triaxial strain gauges attached to the lateral and medial aspects of the distal fragment during maximum load $(1000 \mathrm{~N})$ non-destructive compressive testings.

Bar chart showing largest deformation values $(\mu \mathrm{d})$ sampled via triaxial strain gauges attached to the lateral and medial aspects of the distal fragment during maximum load non-destructive testings, in the control (ND-C), castor oil polyurethane (ND-M) and chitosan (ND-Q) groups. Positive and negative values indicate tension and compression respectively. Source: (MOREIRA, R. C., 2014).

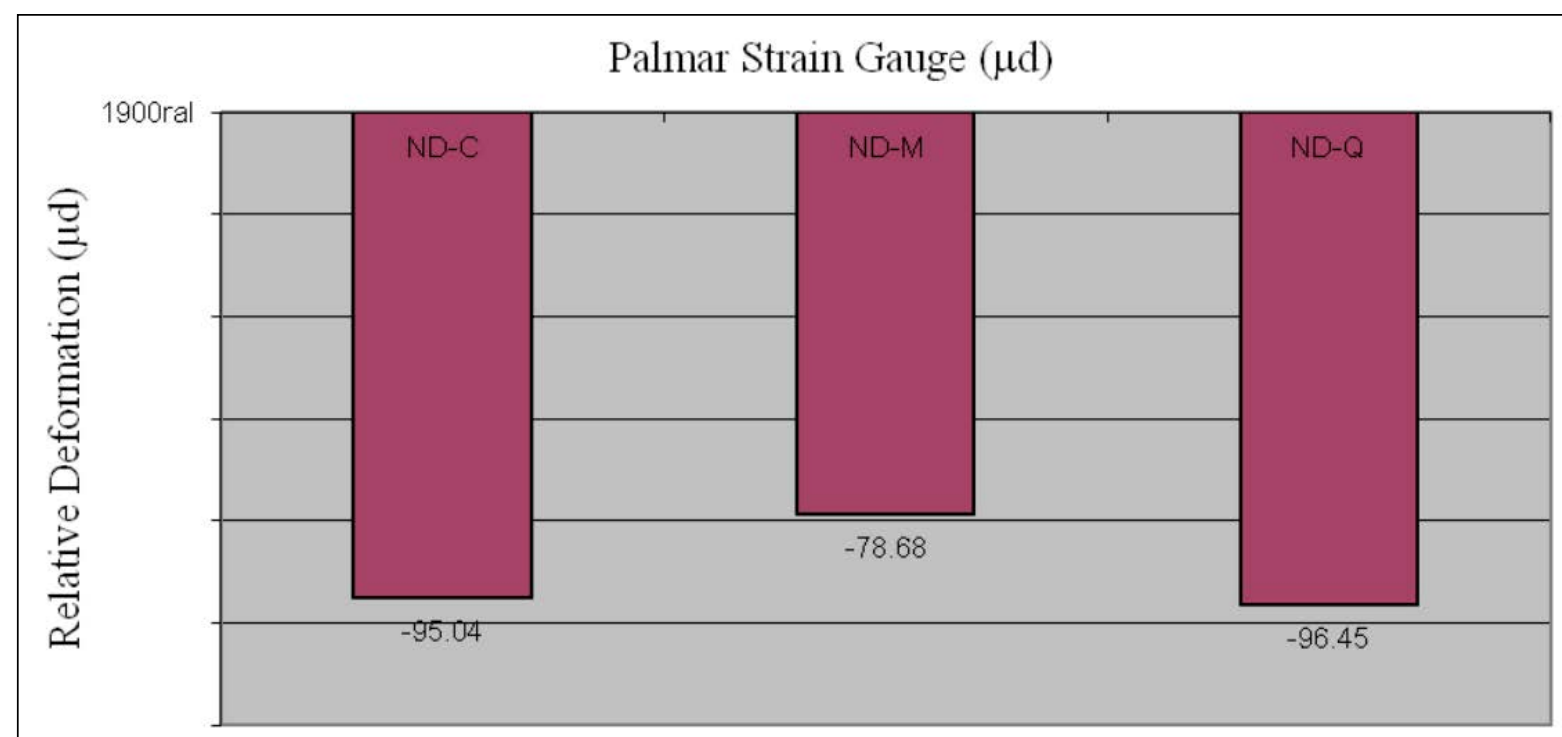

Figure 5 - Deformation readings given by a triaxial strain gauge attached to the palmar aspect of the distal fragment during maximum load $(1000 \mathrm{~N})$ non-destructive compressive testings.

Bar chart showing largest mean deformation values $(\mu \mathrm{d})$ sampled via a triaxial strain gauge attached to the palmar aspect of the distal fragment during maximum load non-destructive testing, in the control (ND-C), castor oil polyurethane (ND-M) and chitosan (ND-Q) groups. Negative values indicated compression. Source: (MOREIRA, R. C., 2014). 


\section{ACKNOWLEDGEMENTS}

This work was funded by the Fundação de Amparo à Pesquisa do Estado de São Paulo (FAPESP) with proces number 2010/17805-3.

\section{REFERENCES}

BI, L. et al. Reconstruction of goat tibial defects using an injectable tricalcium phosphate/chitosan in combination with autologous platelet-rich plasma. Biomaterials, v.31, n.12, p.3201-3211, 2010. Available from: <http:/www.cusabio.cn/ wenxian/167.pdf>. Accessed from: jul. 22, 2016. doi:10.1016/j. biomaterials.2010.01.038.

BOLSON, J. et al. Clinical, radiological, macroscopical and histological analysis of domestic quail (Coturnix japonica) humerus submitted to implant of polyurethane from castor oil polymer (Ricinnus communis). Ciência Rural, v.35, n.5, p.11231130, 2005. Available from: <http://www.studiocalori.it/images/ pdf/pubblicazioni/087.pdf>. Accessed from: jul. 22, 2016.

CALORI, G.M. et al. The use of bone-graft substitutes in large bone defects: Any specific needs? Journal of Care Injured, v.42, p.56-63, 2011. Available from: <http://www.scielo.br/pdf/cr/ v35n5/a21v35n5.pdf $>$. Accessed from: jul. 22, 2016. doi:10.1016/j. injury.2011.06.011

DORNBUSCH, P.T. et al. Avaliação radiográfica da aplicação do polímero de mamona em falhas ósseas induzidas em equinos. Archives of Veterinary Science, v.15, n.1, p.01-08, 2010. Available from: <http://repositorio.unesp. $\mathrm{br} / \mathrm{bits}$ tream/handle/11449/72212/2-s 2.0-78649646540. pdf? sequence $=1 \&$ isAllowed $=\mathrm{y}>$. Accessed from: jul. 22, 2016.

PRZEKORA, A.; GINALSKA, G. Biological properties of novel chitosan-based composites for medical application as bone substitute. Central European Journal of Biology, v.9, n.6, p.634-641, 2014. Available from: <http://www.degruyter.com/ downloadpdf/j/biol.2014.9.issue-6/s11535-014-0297-y/s11535014-0297-y.xml>. Accessed from: jul. 22, 2016. doi: 10.2478/ s11535-014-0297-y.

JACQUES, J.W. et al. The role of the ricin polyurethane as substitute of the bone autogenous graft in rabbits. Revista Colégio Brasileiro Cirurgiões, v.31, n.4, p.236-241, 2004. Available from: <http://www.scielo.br/pdf/rcbc/v31n4/ v31n4a04>. Accessed from: jul. 22, 2016.
LISTONI, A.J. Estudo do potencial de diferenciação de célulastronco mesenquimais equinas oriundas do sangue da medula óssea cultivadas sobre um filme multicamadas de biopolímeros quitosna, HA e CMC. 2013. 59f. Dissertação (Mestrado em que especialidade?) - Instituto de Biociências de Botucatu, Universidade Estadual Paulista Júlio de Mesquita Filho, SP.

MARTINELI JUNIOR, W. Estudo histológico dos tecidos conjuntivo e osteóide em enxertos ósseos com polímero de mamona: estudo experimental em ratos. 2011. 93f. Dissertação (Mestrado em Ciências) - Faculdade de Ciências Médicas Universidade de Campinas, Campinas, SP.

MOREIRA, R.C. Estudo biomecânico do terceiro metacarpiano de equinos. 2008. 55f. Dissertação (Mestrado em Medicina Veterinária) - Faculdade de Medicina Veterinária e Zootecnia, Universidade de São Paulo, SP. Available from: <http://www. teses.usp.br/teses/disponiveis/10/10137/tde-22042009-100210/> Accessed: Jul. 13, 2010

NIXON, A.J. General considerations in selecting cases for fracture repair. In: NIXON, A.J. Equine fracture repair. Philadelphia: Saunders, 1996. Cap. 4, p.30-35.

SPIN-NETO, R. et al. Biomateriais à base de quitosana com aplicação médica e odontológica: revisão de literatura. Revista de Odontologia da UNESP, v.37, n.2, p.155-161, 2008. Available from: <http://www.revodontolunesp.com.br/files/v37n2/v37n2a09. pdf $>$. Accessed from: jul. 22, 2016

ULIAN, V. et al. Primary stabilization of humeral shaft fractures: an experimental study of different osteosynthesis methods. Acta ortopedica brasileira, v.16, n.1, p 8-12, 2008. Available from: $<$ http://www.producao.usp.br/bitstream/handle/BDPI/7127/art MAZZER Estabilizacao primaria da diafise umeral estudo experimental_2008.pdf? sequence $=\overline{1} \& \overline{\mathrm{is}}$ Allowed $=\mathrm{y}>$. A Accesse $\overline{\mathrm{d}}$ from: jul. 22, 2016.

VAN DE GRAAF, G.M.M. Avaliação da resistência mecânica à compressão axial de diferentes formulações de poliuretana de mamona com carbonato de cálcio e de quitosana com fosfato de cálcio. 2012. 84f. Dissertação (Mestrado em Ciências) - Faculdade de Medicina Veterinária e Zootecnia, Universidade de São Paulo, SP.

ZHANG, Y.; ZHANG, M. Three-dimensional macroporous calcium phosphate bioceramics with nested chitosan sponges for load-bearing bone implants. Journal of Biomedical Materials Research, v.61, n.1, p.1-8, 2002. 